\title{
QUAN ĐIỂM CỦA HỒ CHÍ MINH VỀ BẢN CHẤT HƯớNG THIỆN, NHÂN BẢN CỦA TÔN GIÁO VÀ VIÊC PHÁT HUY NHŨ்NG GIÁ TR! VĂN HÓA, ĐẠO ĐỨC TÔN GIÁO Ở VIỆT NAM HIỆN NAY
}

\author{
HỒ VĂN ĐỨC \\ Khoa Lý luận chính trị, Truờng Đại học Công nghiệp Thành phố Hồ Chí Minh \\ hohienminh1118@gmail.com
}

Tóm tắt.Tôn giáo là nhu cầu tinh thần của một bộ phận nhân dân và tôn giáo có những giá trị văn hoá, đạo đức phù hợp với chế độ xã hội. Vì vậy, trong công cuộc xây dựng xã hội mới, việc phát huy những giá trị văn hóa, đạo đức tốt đẹp của tôn giáo có ý nghĩa thiết thực đối với việc đẩy mạnh công tác an sinh xã hội, bảo tồn các giá trị tốt đẹp của văn hóa dân tộc, đạo đức truyền thống, ngăn ngừa sự suy thoái về đạo đức, lối sống do những tác động của mặt trái cơ chế thị trường. Thông qua bài viết này, tác giả góp phần giúp bạn đọc nhận thức rõ hơn quan điểm của Hồ Chí Minh và Đảng Cộng sản Việt Nam về việc khuyến khích phát huy những giá trị văn hóa, đạo đức tốt đẹp của tôn giáo.

Tù khóa: tu tuởng Hồ Chỉ Minh, chính sách tôn giáo, văn hóa và đạo đức tôn giáo.

\section{HO CHI MINH'S VIEWPOINT ON THE NATURE OF GOODNESS, HUMANITY OF RELIGION AND THE PROMOTION OF CULTURAL AND ETHICAL VALUES OF RELIGION IN THE PRESENT OF VIETNAM}

\begin{abstract}
Religion is spiritual demand of a portion of people in Viet Nam having cultural and ethical values suitable to the social regime. Hence, in the process of building a new society, the promotion of the good cultural and ethical values of religion has positive impacts on the development of social life and security, preserving value of the good of the national culture, traditional morality and preventing the deteriotion in morality and lifestyle due to the impacts of the downside of the market economy. By this article, the author wants to help readers become more aware of the viewpoint of views of Ho Chi Minh and the Communist Party of Vietnam on encouraging and promoting of good cultural and moral values of religion.
\end{abstract}

Keywords: Ho Chi Minh thoughts, religious policies, culture and religious morality.

\section{1. ĐẶT VẤN ĐỀ}

Là quốc gia có diện tích không rộng lớn, nhưng ở Việt Nam đang dung nạp và tồn tại nhiều hình thức tín ngưỡng, tôn giáo khác nhau. Từ những hình thức tôn giáo sơ khai đến hiện đại, tín ngưỡng phương Đông đến tôn giáo phương Tây cùng tồn tại bên cạnh những loại hình tín ngưỡng dân gian, bản địa của các cộng đồng dân tộc trong nước. Theo báo cáo của Ban Tôn giáo Chính phủ, hiện nay ở Việt Nam có khoảng $95 \%$ dân số có nhu cầu tín ngưỡng, tôn giáo. Tính đến tháng $8 / 2019$ Nhà nước ta đã công nhận và cấp đăng ký hoạt động cho 43 tổ chức thuộc 16 tôn giáo, với khoảng 26 triệu tín đồ, chiếm hơn $1 / 4$ dân số cả nước, gần 56 nghìn chức sắc, 145.721 chức việc, 29.396 cơ sở thờ tự tôn giáo và khoảng 45.000 cơ sỏ tín ngưỡng, trong đó có hơn 3.000 di tích gắn với tín ngưỡng, tôn giáo, một số được UNESCO công nhận là di sản văn hóa thế giới [1]. Trong tiến trình lịch sử phát triển đất nước ta, tôn giáo có những đóng góp trên nhiều phương diện, trong đó nổi bật nhất là phương diện văn hóa, đạo đức. Những giá trị văn hóa, đạo đức tôn giáo đã góp phần làm cho nền văn hóa Việt Nam thêm phong phú và đặc sắc. Tuy nhiên, ý nghĩa và vai trò của văn hóa, đạo đức tôn giáo trong từng giai đoạn lịch sử cũng được nhìn nhận khác nhau, điều đó phụ thuộc vào quan điểm của chính quyền đối với tôn giáo, cũng như đường hường hoạt động của chính bản thân tôn giáo.

Sinh thời, Chủ tịch Hồ Chí Minh có quan điểm và cách ứng xử đúng đắn đối với tôn giáo. Người luôn có ý thức tìm kiếm, đề cao và khuyến khích phát huy mặt tích cực, điểm tương đồng, những "hạt nhân hợp 
lý” trong tôn giáo. Trong đó, Hồ Chí Minh đặc biệt chú ý khai thác những giá trị văn hóa, đạo đức nhân văn, tư tưởng nhân bản của tôn giáo để lan tỏa trong đời sống xã hội, bồi đắp cho nền văn hóa dân tộc Việt Nam. Đây là bài học lớn quý báu mà Đảng và Nhà nước ta tiếp thu và vận dụng để hoạch định chính sách tôn giáo trong thời kỳ đổi mới đất nước. Hiện nay, bên cạnh chính sách nhất quán là tôn trọng và bảo đảm quyền tự do tín ngưỡng, đoàn kết đồng bào tôn giáo trong khối đại đoàn kết dân tộc, Đảng ta còn khẳng định, "phát huy những giá trị văn hóa, đạo đức tốt đẹp của các tôn giáo" góp phần vào công cuộc xây dựng xã hội mới. Vì vậy, qua bài viết này, tác giả làm rõ những nội dung cơ bản của quan điểm Hồ Chí Minh về bản chất hướng thiện, nhân bản của tôn giáo, cũng như sự vận dụng quan điểm khoa học đó vào quá trình thực hiện chính sách tôn giáo ở Việt Nam hiện nay. Từ đó góp phần tuyên truyền tư tưởng Hồ chí Minh và chính sách của Đảng, Nhà nước Việt Nam về tôn giáo, nâng cao nhận thức của cán bộ, đảng viên, nhân dân về vai trò tích cực của những giá trị văn hóa, đạo đức tôn giáo trong công cuộc đổi mới hiện nay, khi mà chúng ta cần phải huy động mọi nguồn lực tham gia vào sự nghiệp xây dựng đất nước theo định hướng xã hội chủ nghĩa.

\section{QUAN ĐIỂM CỦA HỒ CHÍ MINH VỀ BẢN CHẤT HƯỚNG THIỆN VÀ NHÂN BẢN CỦA TÔN GIÁO}

Vận dụng sáng tạo quan điểm của chủ nghĩa Mác - Lênin về tôn giáo vào điều kiện cụ thể ở Việt Nam, Hồ Chí Minh đã có quan điểm và cách ứng xử đúng đắn đối với vấn đề tôn giáo ở nước ta, góp phần xây dựng khối đoàn kết toàn dân tộc trong công cuộc xây dựng và bảo vệ Tổ quốc. Tư tưởng Hồ Chí Minh về tôn giáo bao gồm một hệ thống những quan điểm, chính sách đối với tôn giáo và công tác tôn giáo ở Việt Nam. Tuy nhiên, trong bài viết này, tác giả chỉ tập trung phân tích làm rõ quan điểm của Hồ Chí Minh về bản chất hướng thiện và nhân bản của tôn giáo.

Trong tác phẩm "Chống Đuyrinh", Ph.Ăngghen viết: "Tất cả mọi tôn giáo chẳng qua chỉ là sự phản ánh hư ảo - vào trong đầu óc của con người - của những lực lượng ở bên ngoài chi phối cuộc sống hàng ngày của họ; chỉ là sự phản ánh trong đó những lực lượng ở trần thế đã mang hình thức những lực lượng siêu trần thế" [2, tr.437]. Như vậy, bản chất sự phản ánh tôn giáo là sự phản ánh hư ảo về thế giới tự nhiên và con người, về các quan hệ xã hội, thậm chí các giá trị văn hóa, các chuẩn mực đạo đức của con người. Xuất phát từ nền tảng của đời sống hiện thực, con người đã tạo dựng nên các biểu tượng tôn giáo, hình thành triết lý tôn giáo, cả những nghi lễ் và tổ chức tôn giáo. Từ những bất lực trong cuộc sống, từ những khát vọng khó vươn tới trong hiện thực, con người đã tô điểm, xây đắp cho các hình tượng của mình những sức mạnh có tính siêu nhiên, mang tính huyền ảo, nhằm xây dựng thế giới khác với con người, đứng trên con người, chi phối con người. Tuy nhiên, cũng chính trong quá trình đó, tôn giáo được tích hợp những giá trị văn hóa, đạo đức của con người.

Tiếp thu quan điểm của các nhà kinh điển chủ nghĩa Mác - Lênin về bản chất của tôn giáo, Hồ Chí Minh tìm thấy cái chung trong giáo lý của các tôn giáo chân chính là đều phản ánh khát vọng về một cuộc sống ấm no, tự do và hạnh phúc của quần chúng nhân dân bị áp bức bóc lột; thấy được giá trị nhân bản của các tôn giáo chân chính là hướng tín đồ, hướng nhân loại tới bình đẳng, tự do, bác ái; có những điều cấm kỵ, răn dạy trong giáo lý các tôn giáo mang giá trị đạo đức và nhân văn sâu sắc, khuyên con người làm những điều lành, điều thiện, điều nhân nghĩa, vươn tới cái đẹp, cái cao cả vì lợi ích bản thân và cộng đồng, tránh làm những điều ác, điều xấu, gian tà, điều bất nhân. Hồ Chí Minh khẳng định: "Học thuyết của Khổng Tử có ưu điểm của nó là sự tu dưỡng đạo đức cá nhân. Tôn giáo Giêsu có ưu điểm của nó là lòng nhân ái cao cả. Chủ nghĩa Mác có ưu điểm của nó là phương pháp làm việc biện chứng. Chủ nghĩa Tôn Dật Tiên có ưu điểm của nó, chính sách của nó thích hợp với điều kiện nước ta. Khổng Tử, Giêsu, Mác, Tôn Dật Tiên chẳng có những ưu điểm chung đó sao? Họ đều muốn mưu hạnh phúc cho loài người, mưu phúc lợi cho xã hội. Nếu hôm nay họ còn sống trên đời này, nếu họ họ̣ lại một chỗ, tôi tin rằng họ nhất định chung sống với nhau rất hoàn mỹ như những người bạn thân thiết" [3, tr.185]. Hay trong một bài đăng trên Báo Nhân dân, Hồ Chí Minh viết: "Chúa Giêsu dạy: Đạo đức là bác ái. Phật Thích Ca dạy: Đạo đức là từ bi. Khổng Tử dạy: Đạo đức là nhân nghĩa” [4, tr.225].

Theo Hồ Chí Minh, giá trị nhân bản, đạo đức của tôn giáo chân chính không chỉ biểu hiện trong hệ thống giáo lý mà còn biểu hiện qua nhân cách người sáng lập các tôn giáo. Nhân cách ấy về tư tưởng là khát vọng hy sinh cho con người, vì con người, về hành động là sự xả thân để mưu hạnh phúc cho con người, phúc lợi cho xã hội. Người cho rằng: "Mục tiêu cao cả của Phật Thích Ca và Chúa Giêsu đều giống nhau: 
Thích Ca và Chúa Giêsu đều muốn mọi người có cơm ăn, áo mặc, bình đẳng, tự do và thế giới đại đồng" [3, tr.239]. Hay trong thư gửi đồng bào Công giáo ngày 25-12-1945, Hồ Chí Minh viết: "Cách một nghìn chín trăm bốn mươi nhăm năm trước, cũng ngày hôm nay, một vị thánh nhân là Đức Chúa Giêsu ra đời. Suốt đời Ngài chỉ hy sinh phấn đấu cho tự do, cho dân chủ. Từ ngày Ngài giáng sinh đến nay đã gần 2000 năm, nhưng tinh thần thân ái của Ngài chẳng những không phai nhạt mà toả ra đã khắp, thấm vào đã sâu" [5, tr.128]. Tinh thần đó cũng được thể hiện trong thư Hồ Chí Minh gửi đồng bào Phật giáo nhân ngày Phật đản năm 1947: "Đức Phật là đại từ đại bi, cứu khổ cứu nạn, muốn cứu chúng sinh ra khỏi khổ nạn Người phải hy sinh tranh đấu, diệt lũ ác ma" [6, tr.197]. Thừa nhận những đóng góp của người sáng lập các tôn giáo cho tự do, hạnh phúc của con người nên Hồ Chí Minh luôn bày tỏ sự tôn trọng của mình đối với các vị ấy. Trong những bức thư, bài viết, lời phát biểu của Chủ tịch Hồ Chí Minh với đồng bào Công giáo, Người thường nói đến Chúa trước khi nói đến Tổ quốc, như: "Tôi cầu nguyện Đức Chúa phù hộ cho đồng bào giữ vững tinh thần ái quốc, đủ sức chống lại giặc Pháp, đặng làm tròn nhiệm vụ thiêng liêng là phụng sự Đức Chúa, phụng sự Tổ quốc" [5, tr.701]. Hồ Chí Minh cũng luôn đề cao người sáng lập các tôn giáo, nêu gương tốt của họ và khuyến khích tín đồ và chức sắc tôn giáo noi theo những tấm gương ấy. Trong lời cảm ơn đồng bào Công giáo ngày 14-10-1945, Người viết: "Đức Giêsu hy sinh vì muốn loài người được tự do hạnh phúc, đồng bào ta cả lương cả giáo cũng vì tự do hạnh phúc cho toàn dân mà hy sinh phấn đấu" [5, tr.50].

Hồ Chí Minh cho rằng, bản chất hướng thiện và nhân bản của tôn giáo, những giá trị về đạo đức trong các tôn giáo chân chính la điểm phù hợp với mục tiêu của chủ nghĩa xã hội, với đường lối của Đảng và Nhà nước Việt Nam; và đó cũng chính là điểm tương đồng để đoàn kết giữa những người có tín ngưỡng tôn giáo với những người không có tín ngưỡng tôn giáo, giữa những người có tín ngưỡng tôn giáo khác nhau trong khối đại đoàn kết toàn dân tộc. Mục tiêu đoàn kết lương giáo trong khối đại đoàn kết toàn dân tộc của Hồ Chí Minh là nhằm đạt ước vọng mà cả cuộc đời Người nguyện hy sinh phấn đấu để thực hiện, đó là độc lập cho dân tộc và hạnh phúc cho nhân dân. Hồ Chí Minh khẳng định: "Ta đoàn kết để đấu tranh cho thống nhất và độc lập của Tổ quốc; ta còn phải đoàn kết để xây dựng nước nhà" [7, tr.438]. Độc lập cho dân tộc và hạnh phúc cho nhân dân cũng được Hồ Chí Minh xem là mẫu số chung để đoàn kết mọi tầng lớp nhân dân Việt Nam, không phân biệt đảng phái, giai tầng xã hội, dân tộc, tôn giáo, già trẻ, gái trai, ở trong nước hay ngoài nước.

Việc phát hiện ra bản chất hướng thiện và nhân bản của các tôn giáo chân chính đã giúp Hồ Chí Minh vượt qua các tư tưởng duy vật tầm thường - "xem tôn giáo chỉ là tập đại thành của những luận thuyết ủy mị, chống lý tính, tử thù của khoa học", đưa ra cách ứng xử đúng đẳn với tôn giáo trong điều kiện cụ thể ở Việt Nam. Đó cũng là cơ sở để Hồ Chí Minh không rập khuôn tiến hành một cuộc đấu tranh về mặt tư tưởng một cách trừu tượng với thế giới quan tôn giáo như thường thấy ở châu Âu; không khai thác những điều khác biệt, trái ngược về thế giới quan giữa chủ nghĩa duy vật và tôn giáo. Ngược lại, Hồ Chí Minh luôn có ý thức tìm kiểm, khai thác những giá trị văn hóa, đạo đức tốt đẹp chứa đựng trong các tôn giáo để kế thừa, bổ sung làm giàu thêm nền văn hóa của nước nhà; phục vụ cho việc xây dựng xã hội mới trên cơ sở độc lập dân tộc và chủ nghĩa xã hội. Tuy nhiên, khẳng định những giá trị văn hóa, đạo đức tốt đẹp chứa đựng trong các tôn giáo hoàn toàn không có nghĩa là Hồ Chí Minh đồng nhất thế giới quan duy vật và thế giới quan duy tâm. Người từng nói chủ nghĩa duy linh và chủ nghĩa duy vật là khác nhau, nhưng không phải vì thế mà bài xích, nghi kỵ, đối đầu nhau, chà đạp lên quyền tự do của nhau; trái lại cần phải tôn trọng tự do tín ngưỡng của công dân, trân trọng những giá trị nhân văn của tôn giáo.

\section{PHÁT HUY NHỮNG GIÁ TRI VĂN HÓA, ĐẠO ĐỨC TỐT ĐẸP CỦA CÁC TÔN GIÁO Ở VIỆT NAM HIỆN NAY}

Học tập và vận dụng quan điểm của Hồ Chí Minh về bản chất hướng thiện và nhân bản của tôn giáo, trong thời kỳ đổi mới đất nước Đảng và Nhà nước Việt Nam chủ trương "phát huy những giá trị văn hóa, đạo đức tốt đẹp của các tôn giáo", nhằm bảo tồn các giá trị tốt đẹp của văn hóa dân tộc, đạo đức truyền thống, huy động mọi nguồn lực từ tôn giáo góp phần xây dựng xã hội mới hiện nay.

Trong thời kỳ đổi mới đất nước, sự khẳng định về những giá trị văn hóa, đạo đức tốt đẹp của các tôn giáo lần đầu tiên được thể hiện ở Nghị quyết 24/NQ-TW ngày 16-10-1990 của Bộ Chính trị "Về tăng cường công tác tôn giáo trong tình hình mới". Nghị quyết này được xem là mốc đánh dấu bước ngoặt trong việc đổi mới tư duy về tôn giáo của Đảng Cộng sản Việt Nam; trong đó có quan điểm mang "tính đột phá" là: 
"Tín ngưỡng, tôn giáo là nhu cầu tinh thần của một bộ phận nhân dân và tôn giáo có những giá trị văn hoá, đạo đức phù hợp với chế độ xã hội mới” $[8$, tr.208]. Quan điểm chỉ đạo này đã nhanh chóng tạo nên sự thay đồi về nhận thức: Không thể nhìn tôn giáo qua mệnh đề của C.Mác đã bị cắt xén và phiến diện "Tôn giáo là thuốc phiện của nhân dân"; hay coi tôn giáo như là "tàn dư" của xã hội cũ, là kết quả sai lầm trong nhận thức của con người, tôn giáo đối lập với chủ nghĩa xã hội, với khoa học, kỹ thuật hiện đại và cần phải loại bỏ... Cần phải nhìn nhận tôn giáo như một "thực tại xã hội" và là nhu cầu của một bộ phận quần chúng và tôn giáo hoàn toàn có thể đồng hành với chủ nghĩa xã hội. Đặc biệt luận điểm mới mẻ về văn hóa, đạo đức tôn giáo đã khơi dậy những suy nghĩ, hành động tích cực của quần chúng có tôn giáo cũng như không có tôn giáo. Khi các giá trị văn hóa, đạo đức của tôn giáo được đặt trong khuôn khổ của văn hóa dân tộc một mặt đã thừa nhận sự đa dạng của văn hóa dân tộc, mặt khác tạo thêm một con đường đoàn kết dân tộc, tôn giáo.

Sau Nghị quyết 24/NQ-TW, quan điểm phát huy những giá trị văn hóa, đạo đức tốt đẹp của các tôn giáo còn được Đảng và Nhà nước khẳng định ở nhiều văn bản, trong đó đáng chú ý nhất là Chỉ thị $37-\mathrm{CT} / \mathrm{TW}$ ngày 2/7/1998 của Bộ Chính trị "Về công tác tôn giáo trong tình hình mới" - Một văn kiện quan trọng lần đầu tiên được đăng tải công khai trên tờ Nhân dân và hàng loạt các tờ báo khác. Nếu Nghị quyết 24 làm sáng tỏ quan điểm của Đảng Cộng sản Việt Nam về nhìn nhận tôn giáo và công tác tôn giáo thì Chỉ thị 37 là sự cụ thể hóa những quan điểm đó bằng việc đề ra những nguyên tắc, chính sách và nhiệm vụ của công tác tôn giáo. Trong các nguyên tắc, đáng chú ý nhất là: "Những hoạt động tôn giáo ích nước lợi dân, phù hợp với nguyện vọng và lợi ích chính đáng, hợp pháp của tín đồ được bảo đảm. Những giá trị văn hóa, đạo đức tốt đẹp của tôn giáo được tôn trọng và khuyến khích phát huy" [9, tr.323]. Chỉ thị cũng đề ra nhiệm vụ mà Đảng và chính quyền các cấp phải thực hiện là: "Hướng dẫn các tôn giáo hoạt động theo hướng: Phát huy những giá trị văn hóa, đạo đức lành mạnh, hướng thiện của tôn giáo phù hợp với truyền thống văn hóa dân tộc và đời sống xã hội; thực hiện tôn giáo gắn bó với dân tộc, đoàn kết hòa hợp đồng bào các tôn giáo cùng toàn dân xây dựng và bảo vệ Tổ quốc" [9, tr.324]. Nhìn một cách tổng thể, Chỉ thị 37 không tạo bước đột phá mà là triển khai Nghị quyết Nghị quyết 24; cô đúc lại những vấn đề quan thiết mà Đảng, Nhà nước từ Trung ương đến địa phương phải thực hiện do nhu cầu thực tế đặt ra.

Tiếp đến, ngày 12-3-2003, Nghị quyết 25-NQ/TW của Ban Chấp hành Trung ương khoá IX "Về công tác tôn giáo" được ban hành, đánh dâu thêm một bước tiến mới trong nhận thức của Đảng ta về lĩnh vực tôn giáo. Nội dung Nghị quyết 25 đến nay vẫn nguyên giá trị, có tính thời sự cao, phù hợp với công cuộc đổi mới của đất nước; chính sách tôn giáo của Đảng và Nhà nước Việt Nam hiện nay vẫn chủ yếu tuân theo những quan điểm chỉ đạo, những nhiệm vụ chủ yếu được thể hiện trong Nghị quyết này. Về văn hóa, đạo đức của tôn giáo cũng được Nghị quyết tái khẳng định: "Đạo đức tôn giáo có nhiều điều phù hợp với công cuộc xây dựng xã hội mới” [10, tr.46]. Để khuyến khích phát huy giá trị văn hóa, đạo đức tôn giáo trong các hoạt động thực tiễn, chia sẽ trách nhiệm với xã hội và đất nước, Đảng ta đưa ra giải pháp: "Giải quyết việc tôn giáo tham gia thực hiện chủ trương xã hội hóa các hoạt động y tế, văn hóa, xã hội, giáo dục... của Nhà nước, theo nguyên tắc: Khuyến khích các tôn giáo đã được Nhà nước thừa nhận tham gia phù hợp với chức năng, nguyên tắc tổ chức của mỗi tôn giáo và quy định của pháp luật. Cá nhân tín đồ, chức sắc, chức việc, nhà tu hành tham gia với tư cách công dân thì được khuyến khích và tạo điều kiện thực hiện theo quy định của pháp luật" [10, tr.54].

Sau Nghị quyết 25-NQ/TW, tinh thần trên tiếp tục được Đảng Cộng sản Việt Nam tái khẳng định trong Báo cáo Chính trị các kỳ Đại hội Đại biểu toàn quốc lần thứ X, XI, XII. Văn kiện Đại hội lần thứ XII (2016) nêu rõ: "Tiếp tục hoàn thiện chính sách, pháp luật về tín ngưỡng, tôn giáo, phát huy những giá trị văn hóa, đạo đức tốt đẹp của các tôn giáo. Quan tâm và tạo điều kiện cho các tổ chức tôn giáo sinh hoạt theo hiến chương, điều lệ của tổ chức tôn giáo đã được Nhà nước công nhận, theo quy định của pháp luật, đóng góp tích cực vào sự nghiệp xây dựng và bảo vệ đất nước" [11].

Quan điểm về văn hóa, đạo đức tôn giáo không chỉ được thể hiện trong chủ trương đường lối của Đảng mà còn được thể chế hóa thành các quy định của pháp luật. Trong Luật tín ngưỡng, tôn giáo số 02/2016/QH14, chủ trương của Đảng về phát huy giá trị văn hóa, đạo đức tốt đẹp của tôn giáo đã được ghi nhận ở một số điều, nhưng đáng chú ý nhất là Điều 3 quy định: "Nhà nước tôn trọng, bảo vệ giá trị văn hóa, đạo đức tốt đẹp của tín ngưỡng, tôn giáo, truyền thống thờ cúng tổ tiên, tôn vỉnh người có công với đất nước, với cộng đồng đáp ứng nhu cầu tinh thần của Nhân dân" $[12, \operatorname{tr} .10]$; Khuyến khích tôn giáo thể hiện tinh thần đạo đức trong thực tiễn cuộc sống, Điều 55 quy định các tổ chức tôn giáo "Được tham 
gia các hoạt động giáo dục, đào tạo, y tế, bảo trợ xã hội, từ thiện, nhân đạo theo quy định của pháp luật có liên quan [12, tr.57]. Việc thể chế hóa thành các quy định của pháp luật như vậy đã tạo ra hành lang pháp lý cho hoạt động tôn giáo, là cơ sở để giải quyết các nhu cầu sinh hoạt tôn giáo, xác định rõ trách nhiệm của các cơ quan quản lý nhà nước về tôn giáo, quyền và nghĩa vụ của các cá nhân, tổ chức tôn giáo đang hoạt động ở Việt Nam; đồng thời cũng thể hiện sự quan tâm của Đảng và Nhà nước Việt Nam đến nhu cầu tín ngưỡng của đồng bào có đạo.

Thực hiện chủ trương, chính sách, pháp luật về tôn giáo của Đảng và Nhà nước, trong thời gian qua tôn giáo ở Việt Nam luôn phát huy truyền thống yêu nước, đoàn kết gắn bó đồng hành cùng dân tộc, tích cực hưởng ứng và tham gia các phong trào thi đua yêu nước, các cuộc vận động do các ban ngành đoàn thể phát động. Tôn giáo ở nước ta đã thực sự trở thành một nguồn lực quan trọng góp phần xây dựng và bảo vệ Tổ quốc. Về lĩnh vực văn hóa, các hoạt động từ thiện xã hội, tham gia chủ trương xã hội hóa y tế, giáo dục... các tổ chức tôn giáo có những đóng góp cụ thể như sau:

Một là, tôn giáo tham gia xây dựng đời sống văn hóa cơ sở. Việt Nam là đất nước đa tín ngưỡng, đa tôn giáo và tín ngưỡng, tôn giáo không chỉ đơn thuần là vấn đề tâm linh, tinh thần mà đó là vấn đề văn hóa, vấn đề đạo đức, lối sống. Các tôn giáo ở Việt Nam thông qua đường hướng hoạt động, thông qua giáo lý, giáo luật luôn tông hướng các tín đồ mở rộng tình yêu thương, sống vị tha, bác ái, bao dung. Các giá trị văn hóa, đạo đức, nhân văn kết tinh ở các tôn giáo được lan tỏa trong đời sống xã hội, góp phần xóa bỏ một số hủ tục lạc hậu, nhất là ở các vùng sâu, vùng xa. Một mặt tôn giáo góp phần chăm lo đời sống tinh thần, giải quyết nhu cầu tâm linh của tín đồ, góp phần hạn chế nảy sinh các loại hình tín ngưỡng mê tín dị đoan; mặt khác giáo lý, giáo luật các tôn giáo đều khuyên răn tín đồ và quần chúng nhân dân tuân thủ pháp luật, không làm những việc trái với đạo đức xã hội, góp phần cải tạo môi trường văn hóa lành mạnh, hướng thiện, sống tương thân tương ái. Văn hóa, đạo đức tôn giáo là một nhân tố tích cực góp phần cho văn hóa Việt Nam ngày càng phát triển phong phú và đa dạng. Trong công cuộc toàn dân đoàn kết xây dựng nông thôn mới, đô thị văn minh do Ủy ban Trung ương Mặt trận Tổ quốc phát động, các tổ chức tôn giáo đã thực hiện tốt công tác tuyên truyền, vận động tín đồ tích cực hưởng ứng, chấp hành pháp luật và làm tròn nghĩa vụ công dân, giữ gìn và bảo vệ môi sinh, đẩy mạnh các hoạt động văn hóa văn nghệ, thể dục thể thao, nếp sống văn hóa, văn minh trong việc cưới, việc tang, lễ hội; đấu tranh với các hoạt động lợi dụng tôn giáo, hoạt động trái pháp luật, mê tín dị đoan. Do đó ở nhiều tỉnh thành trong cả nước đã xây dựng được những làng văn hóa, khu phố văn hóa với nét sinh hoạt đạo đời hòa hợp. Từ các phong trào thi đua đó đã xuất hiện ngày càng nhiều những gương tốt, việc tốt, những gương điển hình, xuất sắc trong lao động sản xuất phát triển kinh tế, giúp nhau xóa đói giảm nghèo. Các tổ chức tôn giáo ở nhiều tỉnh thành đã có nhiều mô hình hay, cách làm sáng tạo, như phong trao thi đua xây dựng xứ họ đạo tiên tiến, ông bà mẫu mực, con cháu thảo hiền, đẹp xóm làng, đẹp nhà cửa, đẹp ruộng vườn, tết của người nghèo, chùa tinh tiến, gia đình công giáo gương mẫu thực thi "tân phúc âm hóa gia đình"... Các phong trào "tốt đời đẹp đạo" lan tảo trong đời sống xã hội đã góp phần làm cho bản sắc văn hóa dân tộc, đạo đức truyền thống nhân văn của con người Việt Nam thêm phong phú, ngăn ngừa được tình trạng suy thoái đạo đức, lối sống thực dụng, vô cảm, thờ ơ của con người trong bối cảnh của toàn cầu hóa và tác động của mặt trái kinh tế thị trường.

Hai là, tôn giáo tham gia chủ trương xã hội hóa y tế, giáo dục, các hoạt động từ thiện xã hội, góp phần đảm bảo an sinh xã hội. Với tinh thần đạo đức hướng thiện là nội dung tiêu biểu của các tôn giáo, thực hiện chủ trương của Đảng, Nhà nước ta về xã hội hóa giáo dục và y tế, trong những năm qua nhiều cơ sở y tế, giáo dục, bảo trợ xã hội do chức sắc tôn giáo thành lập, hoạt động vì mục đích nhân đạo, phi lợi nhuận, chủ yếu là giúp đỡ những người nghèo, những người có hoàn cảnh khó khăn.

Về y tế và chăm sóc sức khỏe cộng đồng: Hoạt động y tế được các tôn giáo triển khai theo hai hình thức chủ yếu là hoạt động thường xuyên và không thường xuyên. Về hoạt động thường xuyên, theo báo cáo của Ban Tôn giáo Chính phủ, cả nước hiện nay có gần 600 cơ sở y tế, phòng khám chữa bệnh từ thiện do các tổ chức tôn giáo ở các tỉnh thành lập ra dưới nhiều hình thức như là tuệ tỉnh đường, trạm xá, phòng khám đa khoa, phòng chẩn trị đông $\mathrm{y}$, phòng nam tủ thuốc... Công giáo có gần 150 trạm xá, Tịnh độ Cư sỹ Phật hội Việt Nam có khoảng 210 hội quán và cũng là phòng thuốc nam phước thiện, Phật giáo có khoảng trên 130 phòng khám đông $\mathrm{y}, 10$ phòng khám tây $\mathrm{y}$, Cao Đài có 93 cơ sở khám chữa bệnh từ thiện. Mỗi năm các cơ sở y tế, phòng khám chữa bệnh của tôn giáo đã khám, bốc thuốc cho hàng vạn lượt bệnh nhân, trong đó ưu tiên khám chữa bệnh, cấp miễn phí thuốc cho người nghèo, những người có hoàn 
cảnh đặc biệt khó khăn, với tổng kinh phí hàng trăm tỷ đồng đã góp phần cùng với chính quyền các cấp chăm lo sức khỏe cho nhân dân tốt hơn [1]. Những hoạt động không thường xuyên, hàng năm các tổ chức tôn giáo còn phối hợp với Hội Chữ thập đỏ, Hội Bảo trợ bệnh nhân nghèo, Hội Y học cổ truyền và đoàn thể các cấp trong việc hỗ trợ chuyến xe chuyển bênh; bữa ăn miễn phí cho bệnh nhân nghèo tại một số bệnh viện; tổ chức đoàn khám và cấp thuốc miễn phí; xây dựng nhà đoàn kết tại các bệnh viện lớn ở Trung ương và địa phương, hàng ngày những nồi cháo tình thương, những bữa cơm miễn phí do chức sắc, tín đồ tôn giáo đảm nhiệm vẫn duy trì đều đặn nhằm chia sẽ, động viên, giúp đỡ bệnh nhân nghèo yên tâm điều trị.

Về giáo dục: Các cơ sở giáo dục do tôn giáo thành lập chủ yếu là tham gia giáo dục mầm non và dạy nghề. Tính đến nay cả nước có khoảng 300 trường mần non, 2000 lớp học tình thương, 12 cơ sở dạy nghề thuộc các tổ chức tôn giáo. Hàng năm các cơ sở dạy nghề tuyển sinh đào tạo hướng nghiệp cho hàng nghìn con em. Sau khi tốt nghiệp ra trường, đa số các học viên đều có việc làm ổn định, có mức thu nhập khá, người lao động từ các cơ sở dạy nghề của các tôn giáo được đánh giá cao về kỷ năng lao động, về trách nhiệm và kỷ luật lao động tốt [1]. Ngoài ra nhiều tổ chức tôn giáo có quỹ học bổng để hỗ trợ học sinh nghèo vượt khó, vận động học sinh đến trường nên tình trạng bỏ học ở nhiều nơi đã cơ bản được chấm dứt. Việc học hành của con em giáo dân được các tôn giáo, chức sắc quan tâm do đó tỷ lệ học sinh tiên tiến, học sinh giỏi ở các trường ngày càng tăng.

Về công tác bảo trợ xã hội: Hiện nay cả nước có gần 800 cở sở bảo trợ xã hội của các tổ chức tôn giáo, đang nuôi dưỡng 12.000 trẻ mồ côi, trẻ em tàn tật, người già cô đơn, bệnh nhân tâm thần, bệnh nhân bị HIV/AIDS, tiếp nhận nhiều nhóm đối tượng có hoàn cảnh khó khăn góp phần chia sẽ với Nhà nước trong việc chăm sóc đối tượng bảo trợ xã hội [1]. Phát huy truyền thống tương thân tương ái, các tổ chức tôn giáo đã tham gia tích cực hoạt động từ thiện nhân đạo, luôn là điểm sáng trong phong trào thi đua yêu nước. Nhiều cơ sở tôn giáo là địa chỉ từ thiện giúp đỡ những mãnh đời khó khăn bất hạnh trong cuộc sống, hỗ trợ sách vỡ, xe đạp cho học sinh, tặng xe lăn cho người tàn tật, tặng quà, tặng bể nước, tặng bảo hiểm y tế, tặng chăn và áo ấm... Hàng năm các tổ chức tôn giáo đã đóng góp hàng nghì tỷ đồng cho hoạt động các cơ sở giáo dục, cơ sở y tế, bảo trợ xã hội và các hoạt động từ thiện. Chỉ tính 6 tháng đầu năm 2019, các tổ chức tôn giáo đã đóng góp cho xã hội khoảng hơi 1 nghìn tỷ đồng về từ thiện xã hội [1]. Nguồn kinh phí này được đóng góp từ chức sắc, tín đồ, các nhà hảo tâm, các doanh nghiệp, cơ sở sản xuất. Những việc làm thiện nguyện, nhân văn tốt đẹp ấy thể hiện vai trò của các tổ chức tôn giáo trong truyền thống đoàn kết, yêu thương, đùm bọc với nhau, tinh thần lá lành đùm lá rách của dân tộc Việt Nam, khẳng định chính sách đúng đắn của Đảng và Nhà nước.

Như vậy, việc phát huy những giá trị văn hóa, đạo đức tốt đẹp của tôn giáo trong thời gian qua đã đạt được những thành tựu rất quan trọng. Những giá trị văn hóa, đạo đức tốt đẹp của tôn giáo không chỉ nằm trong tư tưởng, giáo lý mà đã và đang hiện diện thông qua hành động của đông đảo đồng bào có đạo nhằm vươn tới cuộc sống "tốt đời, đẹp đạo". Tuy nhiên, liên quan đến lĩnh vực văn hóa, đạo đức tôn giáo cũng nảy sinh một số vấn đề:

Một là, xuất hiện một số hiện tượng "tà đạo" có lý thuyết, nghi lễ trái với tôn giáo truyền thống; có những cách hành đạo trái với văn hóa truyền thống, trái với thuần phong mỹ tục của dân tộc nhằm mục đích gây thanh thế cá nhân, thu lợi bất chính về kinh tế, gây bất ổn về tình hình an ninh chính trị, trật tự an toàn xã hội.

Hai là, một số kẻ đã núp bóng, trà trộn và lợi dụng các hình thức sinh hoạt tín ngưỡng, tôn giáo để hành nghề mê tín dị đoan. Nó lôi kéo những người có niềm tin cuồng vọng vào các lực lượng siêu nhiên đến mức độ mê muội với những hành vi cực đoan, thái quá, phi nhân tính, phản văn hóa dẫn tới hậu quả xấu cho cá nhân, cộng đồng về thời gian, tài sản, sức khoẻ và thậm chí cả tính mạng.

Ba là, trước tác động của mặt trái cơ chế thị trường, nhiều tiêu cực đã len lỏi vào sinh hoạt tôn giáo, hiện tượng "buôn thần bán thánh" có chiều hướng gia tăng nhằm lợi dụng niềm tin tôn giáo để trục lợi, vun vén cho cá nhân; một số chức sắc, nhà tu hành tôn giáo bị suy thoái về phẩm hạnh, đạo đức, chạy theo lối sống kim tiền, bị sa ngã vào vòng danh lợi... làm ảnh hưởng đến uy tín của giới chức sắc - "gương mặt văn hoá, đạo đức của tôn giáo, biểu tượng cao đẹp cho tín đồ noi theo".

Bốn là, bên cạnh phần lớn các hoạt động từ thiện của tôn giáo có ý nghĩa tích cực đối với xã hội, thể hiện tinh thần từ bi, bác ái của tôn giáo, thì đã có lúc có nơi bị kẻ xấu lợi dụng, hòng thông qua các hoạt động 
từ thiện xã hội để làm động lực thu hút tín đồ, tập hợp lực lượng, lôi kéo, xúi giục, kích động quần chúng hoạt động vì mục đích chính trị phản động.

Những vấn đề trên đã làm vẩn đục bầu sinh hoạt văn hóa tâm linh. Để giải quyết những vấn đề đó và phát huy hơn nữa những giá trị văn hóa, đạo đức tốt đẹp của các tôn giáo ở Việt Nam phục vụ công cuộc xây dựng xã hội mới hiện nay, tác giả bài báo đề xuất một số giải pháp cơ bản sau:

Thứ nhất, đẩy mạnh công tác tuyên truyền, phổ biến chủ trương đường lối, chính sách, pháp luật về tôn giáo của Đảng và Nhà nước nhằm nâng cao nhận thức của cán bộ, đảng viên, nhân dân, nhất là chắc sắc, chức việc, nhà tu hành và tín đồ các tôn giáo về ý nghĩa, vai trò của những giá trị văn hóa, đạo đức tốt đẹp trong các tôn giáo ở Việt Nam hiện nay.

Thứ hai, tăng cường quản lý nhà nước về hoạt động văn hóa tôn giáo, hoạt động từ thiện xã hội, tham gia chủ trương xã hội hóa y tế, giáo dục của các tổ chức tôn giáo; phát huy vai trò của Mặt trận Tổ quốc, các đoàn thể nhân dân và các hội văn học nghệ thuật trong công tác văn hóa tôn giáo.

Thứ ba, nâng cao hiệu quả công tác vận động quần chúng; đẩy mạnh phong trào thi đua yêu nước, xây dựng cuộc sống "tốt đời, đẹp đạo", xây dựng đời sống văn hóa trong đồng bào có đạo; khuyến khích quần chúng tín đồ, chức sắc, nhà tu hành trong việc giữ gìn, phát huy những giá trị văn hóa, đạo đức tốt đẹp của tôn giáo.

Thứ tư, kịp thời phát hiện và đấu tranh làm thất bại mọi âm mưu lợi dụng tôn giáo để hoạt động vì mục đích ngoài tôn giáo, nhằm bảo đảm các hoạt động tôn giáo diễn ra bình thường đúng theo pháp luật, thanh tịnh bầu sinh hoạt văn hóa tâm linh.

\section{KẾT LUẬN}

Trong quá trình lãnh đạo cách mạng Việt Nam, Hồ Chí Minh rất quan tâm đến việc đoàn kết đồng bào tôn giáo trong khối đại đoàn kết toàn dân tộc; luôn có ý thức khai thác những giá trị văn hóa, đạo đức tôn giáo để kế thừa, bổ sung làm giàu nền văn hóa nước nhà, huy động mọi nguồn lực từ tôn giáo tham gia vào sự nghiệp giải phóng dân tộc, xây dựng và bảo vệ Tổ quốc. Học tập và làm theo tư tưởng của Hồ Chí Minh, trong thời kỳ đổi mới đất nước, Đảng và Nhà nước ta khẳng định "tôn giáo có những giá trị văn hoá, đạo đức phù hợp với chế độ xã hội mới”, cần phải "phát huy những giá trị văn hóa, đạo đức tốt đẹp của các tôn giáo" phục vụ công cuộc xây dựng xã hội mới hiện nay. Với vai trò là một thành tố cấu thành văn hóa, tôn giáo đã góp phần gìn giữ, bồi đắp và làm phong phú các giá trị truyền thống văn hóa, nhân văn có ảnh hưởng tích cực đến đời sống xã hội. Thông qua giáo lý khuyên con người hướng thiện, vị tha, bác ái. Những giới điều trong giáo lý các tôn giáo mang đạo đức và nhân văn sâu sắc, góp phần điều chỉnh hành vi ứng xử của con người. Các tôn giáo cùng với chính quyền và mặt trận Tổ quốc các cấp xây dựng đời sống văn hóa, xây dựng nông thôi mới và phát triển kinh tế - xã hội; cứu trợ thiên tai, chăm lo giúp đỡ người có hoàn cảnh khó khăn, giúp đỡ tiếp cận với các dịch vụ y tế, giáo dục, dạy nghề. Tuy nhiên bên cạnh đó, trong lĩnh vực văn hóa, đạo đức tôn giáo cũng nảy sinh một số hạn chế nhất định. Vấn đề đặt ra là cần phải có những giải pháp phù hợp để khắc phục những hạn chế, đồng thời tiếp tục phát huy vai trò của những giá trị văn hóa, đạo đức tôn giáo trong thực tiễn cuộc sống góp phần xây dựng nền đạo đức mới, nền văn hóa tiên tiến, đậm đà bản sắc dân tộc, đóng góp vào sự phát triển chung của đất nước.

\section{TÀI LIẸU THAM KHẢO}

[1] Ban Tôn giáo Chính phủ: http://www.btgcp.gov.vn/plus.aspx/vi/1

[2] C.Mác và Ph.Ăngghen (2002), Toàn tập, tập 20, Nxb. Chính trị quốc gia, Hà Nội.

[3] Viện Nghiên cứu tôn giáo (1998), Hồ Chí Minh về vấn đề tôn giáo tín nguỡng, Nxb. Khoa học xã hội, Hà Nội.

[4] Hồ Chí Minh (2000), Toàn tập, tập 6, Nxb. Chính trị quốc gia, Hà Nội.

[5] Hồ Chí Minh (2000), Toàn tập, tập 4, Nxb. Chính trị quốc gia, Hà Nội.

[6] Hồ Chí Minh (2000), Toàn tập, tập 5, Nxb. Chính trị quốc gia, Hà Nội.

[7] Hồ Chí Minh (2000), Toàn tập, tập 7, Nxb. Chính trị quốc gia, Hà Nội.

[8] Nguyễn Đức Lữ (2009), Tôn giáo - Quan điểm, chính sách của Đảng và Nhà nuớc Việt Nam hiện nay, Nxb. Chính trị - Hành chính, Hà Nội. 
28 QUAN ĐIỂM CỦA HỒ CHÍ MINH VÈ BẢN CHẤT HƯỚNG THIÊN, NHÂN BẢN CỦA TÔN GIÁO VÀ VIỆC PHÁT HUY NHỮNG GIÁ TRI VĂN HÓA, ĐẠO ĐỨC TỔN GIÁO Ở VIỆT NAM HIỆN NAY

[9] Nguyễn Đức Lữ chủ biên (2007), Lý luận về tôn giáo và chính sách tôn giáo ở Việt Nam, Nxb. Tôn giáo, Hà Nội. [10] Đảng Cộng sản Việt Nam (2003), Văn kiện Hội nghị lần thư bảy Ban Chấp hành Trung uong khóa IX, Nxb. Chính trị quốc gia, Hà Nội.

[11] Đảng Cộng sản Việt Nam (2016), Văn kiện Đại hội Đại biểu toàn quốc lần thư XII, Văn phòng Trung ương Đảng, Hà Nội.

[12] Luật tín ngương, tôn giáo, Nxb. Chính trị quốc gia, Hà Nội, năm 2017.

Ngày nhận bài: 03/03/2020

Ngày chấp nhận đăng: 06/06/2020 